\title{
Analisis Spasial dan Temporal Persebaran Kasus Baru TB Paru BTA (+) di Kabupaten Batang
}

\author{
Arum Siwiendrayanti $^{1}$, Dyah Mahendrasari Sukendra ${ }^{1}$, Dwi Arofah ${ }^{1}$ \\ ${ }^{1}$ Ilmu Kesehatan Masyarakat, Fakultas Ilmu Keolahragaan, Universitas Negeri Semarang \\ Gedung F5 Universitas Negeri Semarang \\ a_shiwi@mail.unnes.ac.id
}

Info Artikel:Diterima Agustus 2017 ; Disetujui Agustus 2018 ; Publikasi Oktober 2018

\begin{abstract}
ABSTRAK
Latar belakang: Case Notification Rate (CNR) Kabupaten Batang tahun 2013 sebesar 73,8/100.000 penduduk. Berdasarkan CNR-nya Kabupaten Batang masuk peringkat ke-9 dari 35 kabupaten/kota di Jawa Tengah. Selain itu, pada tahun 2012-2014 tren kasus baru TB paru BTA positif selalu menurun, kemudian meningkat tahun 2015, dan turun kembali di tahun 2016. Namun, tren tersebut tidak menggambarkan tren kasus baru di tiap kecamatan yang ada di Kabupaten Batang. Tujuan dari penelitian ini adalah untuk mengetahui gambaran secara spasial dan temporal persebaran kasus baru Tb paru BTA positif ditinjau dari kepadatan penduduk, ketinggian wilayah, cakupan rumah sehat, dan cure rate tahun 2012-2016.

Metode: Jenis penelitian yang digunakan dalam penelitian ini adalah analitik kuantitatif dengan studi ekologis menggunakan pendekatan spasial dan temporal. Sampel dalam penelitian ini adalah semua kasus baru TB paru BTA positif dari tahun 2012-2016.

Hasil: Penyebaran kasus baru tidak menunjukkan pola khusus pada pemetaan berdasarkan ketinggian dan kepadatan penduduk. Sebagian penyebaran kasus baru menunjukkan pola penyebaran mengikuti pola cure rate, dan hampir seluruhnya mengikuti pola cakupan rumah sehat. Cure rate tinggi tidak diikuti oleh penurunan jumlah kasus baru pada wilayah dengan cakupan rumah sehat rendah.

Simpulan: Persebaran kasus baru TB paru BTA positif dipengaruhi oleh faktor cakupan rumah sehat. Sedangkan faktor yang lainnya tidak mempengaruhi persebaran kasus baru Tb paru BTA positif di Kabupaten Batang Tahun 2012-2016.
\end{abstract}

Kata Kunci : analisis spasial dan temporal; tuberkulosis paru; Kabupaten Batang

\section{ABSTRACT}

Title: Spatial and Temporal Analysis of AFB Smear-Positive Pulmonary Tuberculosis New Cases Distribution in Batang Regency

Background: Case Notification Rate (CNR) of Batang Regency in 2013 is 73.8 / 100.000 population. Based on its CNR, Batang regency is ranked $9^{\text {th }}$ of 35 regencies / cities in Central Java. In addition, in 2012-2014, the trend of new AFB smear-positive cases of pulmonary tuberculosis always decrease, then increase in 2015, and decrease again in 2016. However, the trend does not reflect the trend of new cases in each sub-district. The purpose of this research is to descript the spread of new cases of AFB smear positive pulmonary tuberculosis spatially and temporally in terms of population density, altitude, coverage of healthy house, and cure rate of 2012-2016.

Method: The type of research used in this study is analytic quantitative with ecological studies using spatial and temporal approach. The samples in this study were all new cases of AFB smear positive pulmonary tuberculosis in 2012-2016.

Result: The distribution of new cases did not indicate a specific pattern on mapping based on altitude and population density. Some of the new case distributions showed the pattern of distribution following a cure rate pattern, and almost entirely following the pattern of healthy house coverage. High cure rates were not followed by a decrease in the number of new cases in areas with low coverage of healthy house. 
Conclusion: The distribution of new cases of AFB smear positive pulmonary tuberculosis is influenced by healthy house coverage factor. While other factors did not affect the distribution of new cases of AFB smear positive pulmonary tuberculosis in Batang Regency in 2012-2016

Keywords: spatial and temporal analysis; pulmonary tuberculosis; Batang Regency

\section{PENDAHULUAN}

Penyakit Tuberkulosis (TB) merupakan penyakit infeksi yang disebabkan oleh bakteri Mycobaterium tuberculosis dan dapat menyerang berbagai organ atau jaringan tubuh. Tuberkulosis paru merupakan bentuk penyakit $\mathrm{Tb}$ yang paling banyak terjadi. Penyakit tuberkulosis ditularkan melalui droplet di udara. ${ }^{1}$

Penyakit $\mathrm{Tb}$ masih menjadi masalah penting bagi kesehatan dunia. Dimana diperkirakan $\mathrm{Tb}$ telah menyerang $1 / 3$ dari penduduk dunia. ${ }^{2}$ Data WHO pada tahun 2014 menunjukkan bahwa penyakit $\mathrm{Tb}$ telah menyerang sebanyak 10,4 juta jiwa dimana 1,8 juta diantaranya meninggal karena penyakitTb. WHO menyatakan bahwa $60 \%$ dari total kasus $\mathrm{Tb}$ di dunia berasal dari 6 negara, yaitu China, India, Indonesia, Nigeria, Pakistan, dan Afrika Selatan. ${ }^{3}$

Dalam Widoyono (2011), disebutkan bahwa penyakit tuberkulosis di Indonesia merupakan penyebab kematian ke-3 dan menduduki urutan ke-10 sebagai penyakit terbanyak di masyarakat. ${ }^{1}$ Berdasarkan Profil Kesehatan Indonesia, pada tahun 2015 ditemukan jumlah kasus tuberkulosis sebanyak 330.910 kasus. Jumlah kasus tertinggi yang dilaporkan, terdapat di provinsi dengan jumlah penduduk yang besar yaitu Jawa Barat, Jawa Timur dan Jawa Tengah. Kasus tuberkulosis di tiga provinsi tersebut sebesar 38\% dari jumlah seluruh kasus baru di Indonesia.

Pada tahun 2013, angka penemuan kasus (CDR) Tb paru BTA + di Jawa Tengah masih dibawah target (100\%), yaitu 58,86\%. Kabupaten Batang merupakan salah satu kabupaten yang terdapat di Jawa Tengah. Berdasarkan Profil Kesehatan Kabupaten Batang pada tahun 2013, angka penemuan kasus (CDR) $\mathrm{Tb}$ di Kabupaten Batang masih rendah sebesar 63,9\% sementara target capaian CDR Jawa Tengah sebesar $100 \%$. Pada tahun tersebut CNR Kabupaten Batang sebesar 73,8/100.000 penduduk. Berdasarkan CNRnya Kabupaten Batang masuk ke peringkat 9 dari 35 Kabupaten/Kota di Jawa Tengah. Angka penemuan kasus (CDR) Tb paru di Kabupaten Batang pada tahun 2016 mengalami penurunan, yaitu menjadi 56,6\% (dari jumlah perkiraan 773 kasus baru hanya mampu menemukan 437 kasus baru Tb paru BTA (+).

Tren penurunan angka insidensi terjadi di Kabupaten Batang, yaitu dari tahun 2012 sampai tahun 2014. Namun, pada tahun 2015, angka insidensi $\mathrm{Tb}$ kembali mengalami peningkatan. Hal tersebut dapat dilihat berdasarkan angka insidensi TB Paru BTA + dari tahun 2012 hingga tahun 2015 di Kabupaten Batang. Masing-masing dari angka insidensi tersebut adalah 70,8 per 100.000 penduduk, 63,38 per 100.000 penduduk, 64,74 per 100.000 penduduk, dan 71,88 per
100.000 penduduk. Peningkatan angka insidensi dari tahun 2014 ke 2015 tersebut diikuti pula dengan peningkatan angka kematian akibat $\mathrm{Tb}$ paru di Kabupaten Batang, yaitu dari 1 per 100.000 penduduk menjadi 3 per 100.000 penduduk. Sementara pada tahun 2016 angka insidensi Tb paru BTA + kembali terjadi penurunan, yaitu dengan angka insidensi sebesar 60,5 per 100.000 penduduk. Namun terdapat 4 kecamatan di Kabupaten Batang yang tidak mengalami penurunan angka insidensi dari tahun 2015 ke 2016.

Empat kecamatan di Kabupaten Batang, yaitu Kecamatan Bandar, Kecamatan Tulis, Kecamatan Kandeman, dan Kecamatan Warungasem, mengalami kenaikan angka insidensidari tahun 2015 ke 2016. Dimana masing-masing angka insidensi dari tahun 2015 ke 2016 adalah Kecamatan Bandar dari 89,82 menjadi 92,97 per 100.000 penduduk, Kecamatan Tulis dari 70 menjadi 72,8 per 100.000 penduduk, Kecamatan Kandeman dari 27,35 menjadi 29,45 per 100.000 penduduk, dan Kecamatan Warungasem dari 86,42 menjadi 129,64 per 100.000 penduduk.

Di Kabupaten Batang, rata-rata angka kesembuhan tuberkulosis (cure rate/CR) dalam 5 tahun terakhir adalah sekitar $88 \%$. Target nasional angka kesembuhan $\mathrm{Tb}$ minimal adalah $85 \%$ Meskipun sudah memenuhi target, pencapaian CR tingkat kecamatan masih menunjukkan disparitas antarwilayah. Pada tahun 2016, dari 15 kecamatan terdapat 4 kecamatan yang CR-nya belum memenuhi target. Widoyono (2011) menyatakan bahwa tercapainya angka target $\mathrm{CR}$, diharapkan mampu memutuskan rantai penularan sehingga penyakit $\mathrm{Tb}$ tidak lagi menjadi masalah kesehatan. ${ }^{1}$

Dalam penelitian Wulandari (2012), diperoleh hasil bahwa terdapat hubungan yang signifikan antara kepadatan penduduk dengan jumlah kasus baru $\mathrm{Tb}$ paru BTA $+(p<0,05)$. Hal tersebut dapat terjadi karena jika kepadatan penduduknya tinggi maka peluang kontak terhadap penderita $\mathrm{Tb}$ lebih besar. ${ }^{4} \mathrm{Di}$ Kabupaten Batang, dijelaskan bahwa persebaran penduduk di Kabupaten Batang belum merata. Dengan demikian, diharapkan mampu menggambarkan persebaran $\mathrm{Tb}$ dan mampu menjawab apakah di Kabupaten Batang persebaran kasus Tb BTA + nya mengikuti perubahan kepadatan penduduk.

Selain itu, faktor rumah sehatpun dapat mempengaruhi kejadian Tb paru. Hal tersebut sesuai dengan penelitian yang dilakukan oleh Mahmuda et al (2014), diperoleh hasil bahwa orang yang memiliki rumah tidak sehat pada status ekonomi rendah memiliki peluang 2,152 kali lebih besar untuk menderita $\mathrm{Tb}$ paru dibandingkan dengan orang yang memiliki rumah sehat. Di Kabupaten Batang distribusi 
cakupan rumah sehatpun tidak merata, terdapat kecamatan dengan cakupan rumah sehat mencapai 94,7 $\%$ terdapat pula yang capaiannya masih $9,3 \%{ }^{5}$

Demikian pula dengan kondisi rata-rata ketinggian wilayah di Kabupaten Batang, rata-rata ketinggian wilayah di tiap kecamatan sangat beragam, dari rata-rata ketinggian setinggi 8 mdpl sampai 800 mdpl. Hal tersebut sesuai dengan hasil penelitian Ayomi et al (2012), ketinggian wilayah mempengaruhi penyebaran kasus tuberkulosis paru di wilayah kerja Puskesmas Sentani. ${ }^{6}$ Hal ini terjadi karena ketinggian wilayah mempengaruhi suhu udara, kelembaban udara, kerapatan oksigen, dan intensitas sinar UV. Dimana hal tersebut merupakan faktor yang berpengaruh terhadap viabilitas $M$. tuberculosis.

Penelitian ini bertujuan untuk mengetahui gambaran secara spasial dan temporal persebaran kasus baru Tb paru BTA positif ditinjau dari kepadatan penduduk, ketinggian wilayah, cakupan rumah sehat, dan cure rate tahun 2012-2016. Untuk mengetahui pola persebaran terhadap penyakit TB dalam kurun waktu 5 tahun terakhir, peneliti menggunakan data sekunder yang ada dan tersedia tiap tahun serta dimungkinkan memiliki hubungan dengan kejadian tuberkulosis. Data sekunder tersebut adalah kepadatan penduduk, cakupan rumah sehat, ketinggian wilayah, dan cure rate. Salah satu pendekatan yang dapat digunakan untuk menggambarkan persebaran kasus berdasarkan paparan faktor risiko suatu penyakit dalam suatu populasi pada periode waktu tertentu adalah studi ekologi dengan pendekatan analisis spasial. Di dalam penelitian ini, persebaran kasus Tb paru BTA positif akan ditinjau dari faktor lingkungan (kepadatan penduduk, ketinggian wilayah, cakupan rumah sehat) dan cure rate.

\section{MATERI DAN METODE}

Jenis penelitian ini adalah penelitian kuantitatif yang bersifat analitik dengan desain studi ekologi. Studi ekologi ini merupakan studi epidemiologi dengan populasi sebagai unit analisis, yang bertujuan untuk mendeskripsikan hubungan asosiasi antara variabel independen dengan variabel dependen. Unit analisis yang digunakan dalam penelitian ini adalah 15 kecamatan di Kabupaten Batang dalam kurun waktu 5 tahun, yaitu dari 2012 sampai 2016. Beberapa data spasial akan dianalisis dengan cara ditumpangsusunkan (overlay) menggunakan perangkat lunak ArcMap 10.1 guna menghasilkan unit pemetaan yang baru dan akan digunakan untuk mengidentifikasi pola hubungan antara variabel bebas dengan variabel terikat.

Secara keseluruhan peta yang dihasilkan terdiri dari 6 komponen utama yang akan membantu dalam proses perkiraan dan analisis hasil. Komponen pertama yaitu identitas kecamatan berupa singkatan dari nama kecamatan untuk memudahkan identifikasi terhadap kecamatan terkait. Komponen kedua yaitu grafik batang guna menggambarkan tren dari kasus baru Tb paru BTA $(+)$ di Kabupaten Batang.Komponen ketiga adalah angka yang menyatakan jumlah kasus baru Tb paru BTA $(+)$ di tiap kecamatan. Komponen keempat merupakan polygone dan polyline yang menggambarkan batas administratif antarkecamatan di Kabupaten Batang. Polygone dan polyline tersebut akan memiliki gradasi warna sesuai dengan data (variabel bebas) yang dimunculkan oleh perangkat lunak spasial. Komponen kelima adalah arsiran garis lurus dan garis miring yang menggambarkan kategori rendah dan tinggi dari cakupan rumah sehat di Kabupaten Batang.Komponen keenam adalah lingkaran berwarna hijau yang berukuran kecil dan besar guna membedakan antara kategori cure rate yang tinggi dan rendah.

Setelah dilakukan pemetaan, maka dilakukan analisis dengan membandingkan variabel bebas dan variabel terikat selama 5 tahun tersebut di tiap kecamatan. Hal tersebut dilakukan untuk mengetahui apakah selama kurun waktu tersebut persebaran kasus baru Tb paru BTA $(+)$ mengikuti perubahan tiap variabel bebas (kepadatan penduduk, cakupan rumah sehat, rata-rata ketinggian wilayah, dan cure rate) yang telah ditentukan. Sehingga dapat dihasilkan kesimpulan variabel yang paling berpengaruh terhadap persebaran Tb paru BTA $(+)$ di Kabupaten Batang. Tabel 1 memberikan informasi singkat untuk memudahkan pembacaan singkatan dari identitas tiap kecamatan di Kabupaten Batang.

Tabel 1. Daftar Singkatan Identitas Kecamatan

\begin{tabular}{llc}
\hline No. & Kecamatan & Singkatan \\
\hline 1 & Warungasem & WRS \\
2 & Batang & BTG \\
3 & Kandeman & KDM \\
4 & Tulis & TLS \\
5 & Subah & SBH \\
6 & Banyuputih & BNP \\
7 & Gringsing & GSG \\
8 & Tersono & TSN \\
9 & Limpung & LPG \\
10 & Pecalungan & PCL \\
11 & Bandar & BDR \\
12 & Wonotunggal & WTL \\
13 & Blado & BLD \\
14 & Reban & RBN \\
15 & Bawang & BWG \\
\hline
\end{tabular}




\section{HASIL DAN PEMBAHASAN}

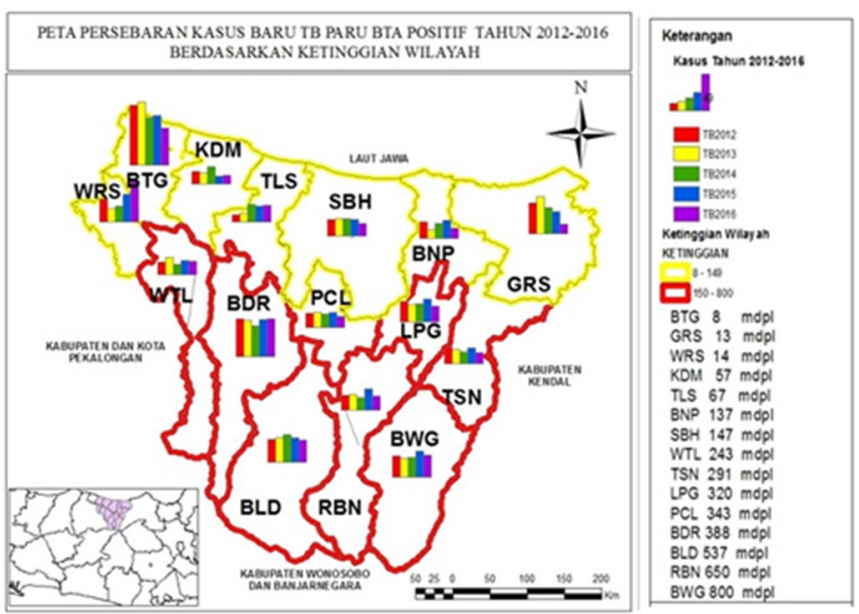

Gambar 1. Peta overlay persebaran kasus Tb paru BTA positif berdasarkan ketinggian wilayah
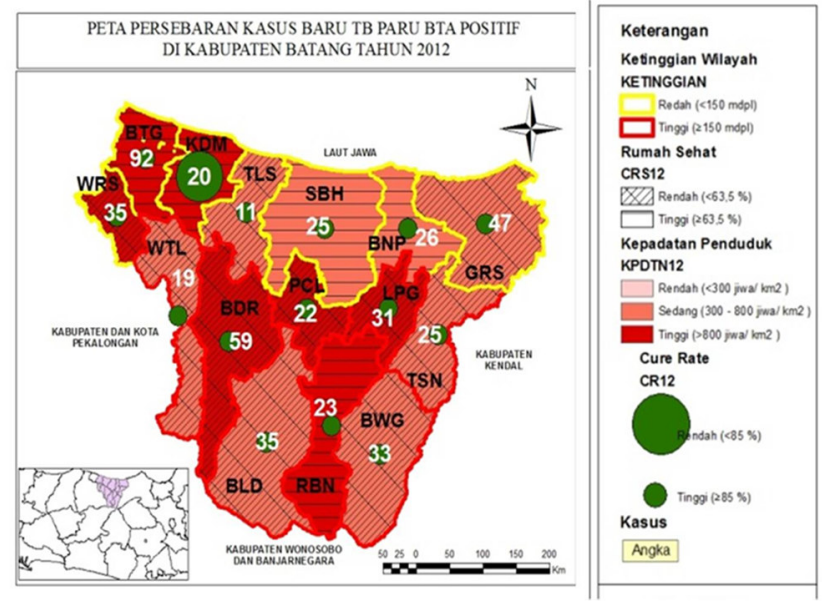

Gambar 2. Peta overlay persebaran kasus baru Tb paru BTA positif tahun 2012



Gambar 3. Peta overlay persebaran kasus baru Tb paru BTA positif tahun 2013 




Gambar 4. Peta overlay persebaran kasus baru Tb paru BTA positif tahun 2014


Gambar 5. Peta overlay persebaran kasus baru Tb paru BTA positif tahun 2015


Gambar 6. Peta overlay persebaran kasus baru Tb paru BTA positif tahun 2016 
Gambar 2 sampai dengan Gambar 6 merupakan tampilan peta overlay persebaran kasus baru Tb Paru BTA positif berdasarkan kepadatan penduduk, ketinggian wilayah, cakupan rumah sehat, dan cure rate dari tahun 2012 hingga tahun 2016. Masingmasing variabel dalam analisis spasial dilakukan suatu pengkategorian. Pengkategorian didapatkan dari beberapa referensi penelitian terdahulu maupun dari peraturan yang ada pada intansi terkait. Pada penelitian ini terdapat satu varibel yang nilainya tidak pernah berubah untuk tiap tahunnya, yaitu ketinggian wilayah. Oleh sebab itu, digunakan satu peta overlay antara ketinggian wilayah dengan kasus baru Tb paru BTA positif tahun 2012-2016 untuk mempermudah dilakukannya analisis (Gambar 1).

Dye et al (2010) mengemukakan dalam hasil studinya bahwa kepadatan penduduk menjadi hal yang penting untuk dikendalikan dalam rangka pengendalian penyakit tuberkulosis. ${ }^{7}$ Penelitian Tanrikulu et al (2008) menunjukkan bahwa ketinggian wilayah dan kepadatan penduduk berkontribusi terhadap kejadian tuberkulosis, dimana wilayah dataran rendah lebih berisiko 3,28 kali lebih besar untuk memiliki jumlah kasus tuberkulosis yang tinggi dan wilayah dengan kepadatan penduduk lebih dari 80 jiwa $/ \mathrm{km}^{2}$ berisiko 4,18 lebih besar untuk memiliki jumlah kasus tuberkulosis tinggi. Ketinggian wilayah akan mempengaruhi suhu, udara, dan kelembaban di dalam rumah sehingga mampu mempengaruhi kehidupan dari Mycobacterium tuberculosis. ${ }^{8}$ Namun, pada penelitian ini memberikan hasil bahwa ketinggian wilayah dan kepadatan penduduk tidak berkaitan dengan kasus baru Tb paru BTA positif. Terdapat berbagai kemungkinan yang dapat terjadi. Penelitian ini menggunakan rata-rata kepadatan penduduk dan ketinggian wilayah kecamatan dan tidak menggambarkan kepadatan penduduk dan ketinggian wilayah di wilayah rumah tinggal tiap penderita.

Pada kategori ketinggian wilayah yang rendah, terdapat 3 kecamatan yang mengalami naik turun jumlah kasus baru Tb paru BTA positif tahun 2012-2016. Kecamatan tersebut adalah Kecamatan Kandeman, Tulis, dan Banyuputih. Selama periode tersebut, Kecamatan Kandeman pada kondisi kepadatan penduduk yang padat dengan dengan ketinggian wilayah 57 mdpl memiliki kecenderungan tren persebaran kasus berbanding terbalik dengan persentase cakupan rumah sehat. Pada tahun 20122013 cakupan rumah sehat di kecamatan tersebut tinggi, diikuti penurunan jumlah kasus baru Tb paru BTA positif. Kemudian pada periode 2013-2014 cakupan rumah sehat menjadi rendah dan diikuti kenaikan jumlah kasus baru Tb paru BTA positif. Demikian pula yang terjadi pada periode 2015-2016. Sedangkan capaian cure rate di kecamatan tersebut selalu rendah, kecuali pada periode 2015-2016. Namun, jumlah kasusnya meningkat.

Kecamatan Tulis dan Banyuputih merupakan 2 kecamatan dengan kepadatan penduduk sedang dengan ketinggian wilayah yang tidak jauh berbeda, yaitu 67 mdpl dan 137 mdpl. Pada kondisi tersebut, Kecamatan Banyuputih memiliki kecenderungan tren persebaran kasus baru Tb paru BTA positif yang mengikuti peningkatan maupun penurunan terhadap cakupan rumah sehat dan cure rate. Hal tersebut dapat terlihat pada periode 2013-2014, Kecamatan Banyuputih memiliki cakupan rumah sehat yang tinggi tetapi kasusnya meningkat. Hal tersebut terjadi karena pada periode tersebut cure rate mengalami penurunan. Kemudian pada periode selanjutnya, pada kondisi cakupan rumah sehat yang memburuk, terjadi peningkatan kasus. Demikian sebaliknya yang terjadi pada periode selanjutnya. Sedangkan di Kecamatan Tulis, persebaran kasus Tb paru BTA positif yang mengikuti cakupan rumah sehat dan cure rate hanya terjadi pada periode 2012-2013. Namun, pada tahun 2016 terdapat penelitian yang menyatakan bahwa kondisi rumah dalam hal ini adalah kelembaban dan pencahayaan mempengaruhi $\mathrm{Tb}$ paru di wilayah Kecamatan Tulis. ${ }^{9}$ Pada kondisi cakupan rumah sehat yang rendah dan cure rate yang menurun, diikuti kenaikan jumlah kasus Tb paru BTA positif. ${ }^{10,11}$ Sedangkan pada 3 periode selanjutnya, cure rate tidak mempengaruhi jumlah kasus baru Tb paru BTA positif. Pada tahun 2013-2014 dan 2015-2016, cakupan rumah sehat yang rendah diikuti pula kenaikan kasus baru $\mathrm{Tb}$ paru BTA positif.

Pada tahun 2013-2016, Kecamatan Gringsing, Batang, dan Subah cenderung mengalami penurunan kasus. Namun, pada periode tersebut terdapat pula kecamatan yang mengalami kenaikan kasus, yaitu Kecamatan Warungasem. Kecamatan Batang, Gringsing, dan Warungasem memiliki ketinggian wilayah yang tidak jauh berbeda. Masing-masing ketinggian wilayahnya adalah $8 \mathrm{mdpl}, 13 \mathrm{mdpl}$, dan 14 mdpl. Pada periode 2012-2014, Kecamatan Gringsing memiliki kepadatan penduduk yang sedang, kemudian menjadi padat pada tahun 2015. Namun, perubahan kepadatan penduduk yang menjadi padat tersebut tidak diikuti kenaikan kasus melainkan terjadi penurunan kasus. Cakupan rumah sehat di Kecamatan tersebut mempengaruhi jumlah kasus baru Tb paru BTA positif pada periode 2012-2013 dan 2014-2015. Sementara pada periode 2013-2014, turunnya jumlah kasus baru dipengaruhi oleh naiknya cure rate yang dicapai Kecamatan Gringsing.

Kecamatan Batang dan Warungasem memiliki kepadatan penduduk yang padat. Namun, tren kasus barunya berbeda. Kabupaten Batang dengan kasus tertingginya, cenderung mengalami penurunan di 3 periode terakhir. Pada periode 2012-2013 dan 20142015, kasus baru Tb paru BTA positif dipengaruhi oleh cakupan rumah sehat. Terjadi kenaikan kasus pada kondisi rumah sehat yang menurun atau pada kondisi cakupan rumah sehat yang rendah. Sedangkan capaian cure rate yang tinggi tidak mempengaruhi jumlah kasus baru BTA positif. Sementara Kecamatan Warungasem mengalami kenaikan kasus dengan tren mengikuti cakupan rumah sehat meskipun pada kondisi capaian cure rate yang tinggi. Pada tahun 2012-2013, 
cakupan rumah sehat di Kecamatan Warungasem mengalami perubahan dari rendah menjadi tinggi yang diikuti dengan berkurangnya jumlah kasus baru. Kemudian pada kondisi cakupan rumah sehat yang memburuk, kasus kembali naik dan terus mengalami kenaikan pada kondisi cakupan rumah sehat yang tetap rendah.

Kecamatan Subah merupakan kecamatan dengan kepadatan penduduk sedang pada ketinggian wilayah sekitar 147 mdpl. Tren kasus cenderung mengalami penurunan meskipun pada kondisi cakupan rumah sehat yang tinggi dan capaian cure rate yang tinggi pula. Namun, pada periode pertama (tahun 20122013) mengalami kenaikan kasus pada kondisi cakupan rumah sehat yang memburuk atau dari cakupan rumah sehat yang tinggi menjadi rendah. Dengan kata lain, pada periode tersebut cakupan rumah sehat mempengaruhi kasus baru Tb paru BTA positif.

Sedangkan pada ketinggian wilayah yang tinggi, tren kasus baru Tb paru BTA positif cenderung fluktuatif. Hal tersebut terjadi di semua kecamatan yang berada di ketinggian $\geq 150 \mathrm{mdpl}$. Kecamatan tersebut adalah Kecamatan Limpung, Pecalungan, Bandar, Blado, Reban, Wonotunggal, Tersono, dan Bawang. Kecamatan Wonotunggal dan Tersono merupakan kecamatan dengan kepadatan penduduk yang sedang dengan ketinggian wilayah tidak berbeda jauh. Kecamatan Wonotunggal memiliki ketinggian wilayah berkisar $243 \mathrm{mdpl}$, sedangkan Kecamatan Tersono memiliki ketinggian wilayah $291 \mathrm{mdpl}$. Selama tahun 2012-2016, kedua kecamatan tersebut memiliki cakupan rumah sehat dengan kategori rendah. Sedangkan kategori cure rate keduanya pun sama, yaitu termasuk dalam kategori tinggi. Kedua variabel tersebut tidak mempengaruhi kasus baru Tb paru BTA positif di Kecamatan Tersono maupun Wonotunggal.

Selanjutnya, terdapat 3 kecamatan yang berada pada ketinggian wilayah dikisaran 300-an mdpl dengan kepadatan penduduk yang tinggi. Kecamatan tersebut adalah Kecamatan Limpung dengan ketinggian 320 mdpl, Kecamatan Pecalungan dengan ketinggian 343 mdpl, dan Kecamatan Bandar dengan ketinggian 388 mdpl. Selama tahun 2012-2016, ketiga kecamatan tersebut memilki capaian cure rate dalam kategori tinggi. Kecuali di Kecamatan Pecalungan pada tahun 2015-2016 yang mengalami penurunan. Secara keseluruhan capaian cure rate di ketiga kecamatan tersebut tidak mempengaruhi kasus baru $\mathrm{Tb}$ paru BTA positif.

Sedangkan untuk variabel cakupan rumah sehat, di Kecamatan Limpung dan Bandar terlihat bahwa cakupan rumah sehat mempengaruhi persebaran kasus baru Tb paru BTA positif di kedua kecamatan tersebut. Dimana ketika cakupan rumah sehatnya mengalami peningkatan maka jumlah kasus baru yang ditemukan berkurang. Demikian sebaliknya. Di Kecamatan Limpung pada tahun 2012-2013 mengalami kenaikan cakupan rumah sehat dari kategori rendah menjadi tinggi yang diikuti dengan turunnya jumlah kasus baru. Kemudian pada periode selanjutnya, cakupan rumah sehat kembali menurun dan tetap pada kategori rendah. Kondisi tersebut diikuti dengan kenaikan jumlah kasus baru Tb paru BTA positif. Sedangkan di Kecamatan Pecalungan, dapat dikatakan bahwa cakupan rumah sehat tidak begitu mempengaruhi kasus baru Tb paru BTA positif karena pada kondisi cakupan rumah sehat yang selalu rendah, tren kasus baru yang terjadi fluktuatif.

Selanjutnya terdapat 3 kecamatan dengan ketinggian wilayah yang berbeda-beda dan dapat dikatakan bahwa ketiga kecamatan tersebut merupakan wilayah dengan ketinggian tertinggi di Kabupaten Batang. Kecamatan Blado dengan ketinggian 537 mdpl, Kecamatan Reban dengan ketinggian 650 mdpl, dan Kecamatan Bawang dengan ketinggian 800 mdpl. Ketiga kecamatan tersebut memiliki capaian cure rate yang tinggi, sementara tren kasus baru fluktuatif. Oleh karena itu, dapat diambil kesimpulan bahwa diketiga kecamatan tersebut cure rate tidak mempengaruhi persebaran kasus baru Tb paru BTA positif. Dalam 4 periode, Kecamatan Reban dan Bawang dapat dikatakan bahwa cakupan rumah sehat tidak mempengaruhi persebaran kasus baru Tb paru BTA positif. Keduanya memiliki tren kasus yang fluktuatif dengan cakupan rumah sehat di Kecamatan Reban selalu tinggi sedangkan di Kecamatan Bawang selalu rendah. Sedangkan di Kecamatan Blado, cakupan rumah sehat terlihat mempengaruhi persebaran kasus baru Tb paru BTA positif. Tahun 2012-2014, ketika cakupan rumah sehat pada kategori rendah, kasus baru Tb paru meningkat. Sedangkan pada tahun 2014-2016, cakupan rumah sehat dari kategori rendah menjadi tinggi yang diikuti dengan penurunan jumlah kasus baru Tb paru BTA positif.

Berdasarkan uraian diatas, persebaran kasus baru Tb paru BTA positif tersebar disemua wilayah kecamatan dengan kepadatan sedang-tinggi. Jadi, dapat disimpulkan bahwa kepadatan penduduk tidak mempengaruhi kasus baru Tb paru BTA positif di Kabupaten Batang dalam kurun waktu 5 tahun terakhir (2012-2016). Sama halnya dengan hasil penelitian yang dilakukan oleh Nida (2014) bahwa secara spasial tidak ada korelasi antara kejadian $\mathrm{Tb}$ dengan kepadatan penduduk di Kota Tangerang Selatan pada Tahun 2009-2013. ${ }^{12}$

Pada ketinggian wilayah yang tinggi $(\geq 150$ mdpl) kasus baru Tb paru BTA positif cenderung fluktuatif. Sedangkan pada ketinggian wilayah yang rendah terdapat 3 kecamatan yang tren kasusnya fluktuatif, yaitu Kandeman, Tulis, dan Batang. Kecamatan Batang, Gringsing, dan Subah mengalami penurunan kasus. Sedangkan Kecamatan Warungasem mengalami kenaikan kasus. Jika ditinjau dari persebaran jumlah kasusnya, maka dapat dikatakan bahwa ketinggian wilayah tidak mempengaruhi kasus baru Tb paru BTA positif. Meskipun kasus tertinggi selalu terjadi di wilayah Kabupaten Batang dengan ketinggian wilayah terendah (8 mdpl dan $14 \mathrm{mdpl}$ ).

Hasil penelitian ini sejalan dengan hasil penelitian yang dilakukan oleh Ruswanto (2010) 
bahwa hasil uji statistik bivariat menunjukkan nilai $\rho$ value $>0,05$, diperoleh nilai $\rho=0,073$ dan $\mathrm{OR}=0,453$ dengan CI 95\% 0,173<OR $<1,097$, sehingga tidak ada hubungan yang bermakna, dengan demikian dapat dinyatakan bahwa ketinggian wilayah bukan merupakan faktor risiko terhadap kejadian tuberkulosis paru pada wilayah tersebut. ${ }^{13}$

Dalam penelitian ini, terdapat 10 kecamatan yang menunjukkan adanya keterkaitan antara cakupan rumah sehat dengan kasus baru Tb paru BTA positif. Kecamatan tersebut adalah Kecamatan Kandeman, Tulis, Banyuputih, Gringsing, Batang, Warungasem, Subah, Limpung, dan Blado. Sedangkan 4 kecamatan lainnya tidak menunjukkan adanya keterkaitan antara kedua variabel tersebut adalah Kecamatan Tersono, Wonotunggal, Pecalungan, Reban, dan Bawang. Dengan demikian. Dapat dikatakan bahwa persebaran kasus baru Tb paru BAT positif di kabupaten Batang dipengaruhi oleh cakupan rumah sehat.

Adanya keterkaitan cakupan rumah sehat dengan kasus baru Tb paru BTA positif dalam penelitian ini, diperkuat dengan pernyataan yang dikemukakan Long (2012) dalam Mahmuda et al (2014) bahwa kondisi rumah dapat secara langsung mempengaruhi penularan $\mathrm{Tb}$. Adapun kondisi fisik rumah yang biasanya berasosiasi terhadap penyebaran $\mathrm{Tb}$ paru adalah kurangnya ventilasi, hunian rumah yang terlalu padat, dan kurangnya cahaya matahari yang masuk dalam rumah. ${ }^{5}$

Pada variabel yang terahir, yaitu cure rate, berdasarkan analisis spasial diatas kecamatan yang memberikan hasil bahwa cure rate berhubungan dengan kasus baru Tb paru BTA positif adalah Kecamatan Tulis, Gringsing, dan Banyuputih. Namun, secara keseluruhan tidak ada hubungan antara kedua variabel tersebut. Dapat dikatakan demikian karena pada masing-masing kecamatan capaian peningkatan/penurunan cure rate yang dikuti dengan bertambah/berkurangnya kasus baru $\mathrm{Tb}$ paru hanya terjadi dalam 1 periode. Jadi, secara keseluruhan hal tersebut dapat dikatakan bahwa cure rate tidak mempengaruhi jumlah kasus baru Tb paru BTA positif di Kabupaten Batang tahun 2012-2016.

Di Kabupaten Batang rata-rata capaian angka kesembuhan diatas $90 \%$ Hal tersebut dapat disimpulkan bahwa telah mencapai target. Namun, pada kenyataannya pencapaian keberhasilan angka kesembuhan belum mampu menekan terjadinya kasus Tb paru. Dengan kata lain, pencapaian tingginya angka kesembuhan tidak diikuti oleh turunnya kasus atau sebaliknya.

Jika dijabarkan, angka kesembuhan diperoleh dari total kasus (semua jenis $\mathrm{Tb}$ paru) yang sembuh dibagi dengan total kasus (semua jenis Tb paru) yang diobati. Dari data yang diperoleh, semua kasus baru yang tercatat di Dinas Kesehatan telah melakukan pengobatan. Sehingga capaian cure rate yang dihasilkan sebanding dengan jumlah temuan kasus. Jika dengan capaian yang tinggi masih saja tidak berpengaruh terhadap persebaran $\mathrm{Tb}$ paru, maka hal tersebut mungkin dipengaruhi oleh beberapa faktor dari indikator program pengendalian Tb yang lain. ${ }^{1}$ Dalam hal ini adalah cakupan penemuan kasus. Namun, dalam penelitian ini peneliti tidak meninjau persebaran kasus dari segi cakupan penemuan kasus sehingga tidak dapat dipastikan keterkaitan antara kedua variabel tersebut. Penemuan kasus dipengaruhi pula oleh teknik petugas kesehatan dalam menentukan cara menemukan kasus. Berdasarkan keterangan yang dinyatakan oleh salah satu staf bidang P2P Dinas Kesehatan Kabupaten Batang, teknik yang dilakukan seringkali masih bersifat pasif dan masih kurangnya kader $\mathrm{Tb}$ yang terbentuk.

Kecamatan Batang dan Warungasem adalah kecamatan dengan karakteristik wilayah yang hampir sama. Keduanya memiliki tingkat kepadatan penduduk tertinggi di Kabupaten Batang. Rata-rata kepadatan penduduk Kecamatan Batang adalah 3433 jiwa $/ \mathrm{km}^{2}$ dan Kecamatan Warungasem adalah 2044 jiwa $/ \mathrm{km}^{2}$. Kedua Kecamatan tersebut berada pada ketinggian wilayah yang tidak jauh berbeda, yaitu 8 mdpl dan 14 mdpl. Namun, jumlah kasus yang ditemukan dan trennya berbeda jauh. Pertama, berdasarkan analisis diatas, cakupan rumah sehat di Kabupaten yang mengikuti tren kasus baru $\mathrm{Tb}$ paru BTA positif hanya pada periode 2012-2013 dan 20142015. Sedangkan di Kecamatan Warungasem tren kedua variabel tersebut selalu berkaitan. Kedua, lokasi kedua wilayah tersebut berdekatan. Perbedaan dari kedua wilayah tersebut adalah Kecamatan Batang merupakan pusat pemerintahan Kabupaten Batang. Dengan kepadatan penduduk yang tertinggi dan menjadi pusat pemerintahan, maka terdapat peluang lebih besar untuk berinteraksi. Hal tersebut memudahkan terjadinya persebaran kasus baru Tb paru BTA positif di Kecamatan Batang. Sedangkan Kecamatan Warungasem merupakan daerah pedesaan atau dapat dikatakan bukan pusatnya keramaian sehingga kemungkinan antarindividu untuk berinteraksi lebih sedikti dibandingkan dengan Kecamatan Batang.

\section{SIMPULAN}

Aspek temporal menunjukkan bahwa mulai tahun 2015 hanya Kecamatan Gringsing yang mengalami perubahan tingkat kepadatan penduduk dari yang sebelumnya sedang menjadi tinggi. Peningkatan kepadatan penduduk di Kecamatan Gringsing mulai tahun 2015 tidak mengakibatkan peningkatan angka kasus baru. Aspek temporal juga menunjukkan bahwa sebagian besar kecamatan mengalami penurunan cakupan rumah sehat seiring dengan bertambahnya tahun dan jumlah penduduk. Aspek spasial berupa ketinggian wilayah tidak terlihat memberikan kontribusi yang nyata terhadap persebaran kasus baru.

\section{DAFTAR PUSTAKA}

1. Widoyono. Penyakit Tropis. Semarang: Erlangga; 2011 
2. Nizar M. Pemberantasan dan Penanggulangan Tuberkulosis. Yogyakarta: Gosyen Publising; 2010

3. World Health Organization. WHO Global Tuberculosis Report 2016. Switzerland: WHO Press; 2016

4. Wulandari F. Analsis Spasial Tuberkulosis Paru BTA (+) di Jakarta Selatan Tahun 2006-2010. Skripsi. Depok: Universitas Indonesia; 2012

5. Mahmuda D, Rahmaniati M. Hubungan Status Rumah Sehat dengan Kejadian Tuberkulosis Paru di Provinsi Banten Tahun 2010 (Analisis Data Riset Kesehatan Dasar Tahun 2010). Depok: Departemen of Biostatistict and Population Studies, Universitas Indonesia; 2014

6. Ayomi A.C, Setiani O, Joko T. Faktor Risiko Lingkungan Fisik Rumah dan Karakteristik Wilayah sebagai Determinan Kejadian Penyakit Tuberkulosis Paru di Wilayah Kerja Puskesmas Sentani Kabupaten Jayapura Povinsi Papua. Jurnal Kesehatan Lingkungan Indonesia 2012, 11(1): 1-8

7. Dye C, Williams B.G. The Population Dynamics and Control of Tuberculosis. Science 2010, 328(5980): 856-861

8. Tanrikulu A.C, Acemoglu H, Palanci Y, Dagli C.E. Tuberculosis in Turkey: high altitude and other socio-economic risk factors. Public Health 2008, 122(6): 613-619
9. Indriyani N, Istiqomah N, Anwar M.C. Hubungan Kelembaban Rumah dengan Kejadian Tuberkulosis Paru di Kecamatan Tulis Kabupaten Batang. Unnes Journal of Public Health 2016, 5(3): 214-220

10. Piubello A, Harouna S.H, Souleymane M.B, Boukary I, S. Morou, Daouda M, Hanki Y, Deun AV. High cure rate with standardised short-course multidrugresistant tuberculosis treatment in Niger: no relapses. The International Journal of Tuberculosis and Lung Disease 2014, 18(10):1188-1194

11. Ai X, Men K, Guo L, Zhang T, Zhao Y, Sun X, Zhang H, He G, Werf M.J, Hof S. Factors associated with low cure rate of tuberculosis in remote poor areas of Shaanxi Province, China: a case control study. BMC Public Health 2010, 10:112

12. Nida S. Epidemiologi Spasial Kejadian Tuberkulosis (Tb) di Kota Tangerang Selatan Tahun 2009-2013. Skripsi. Jakarta: Universitas Islam Negeri Syarif Hidayatullah; 2014

13. Ruswanto B, Nurjazuli, Raharjo M. Analisis Spasial Sebaran Kasus Tuberkulosis Paru Ditinjau Dari Faktor Lingkungan Dalam dan Luar Rumah di Kabupaten Pekalongan. Jurnal Kesehatan Lingkungan Indonesia 2012, 11(1): 22-28 